\title{
Forensic genetic case study: Species identification and traceability of sea turtle caught in illegal trade in Bali, Indonesia
}

\author{
NI PUTU DIAN PERTIWI ${ }^{1, \bullet}$, MAULID DIO SUHENDRO ${ }^{2}$, NI LUH ASTRIA YUSMALINDA ${ }^{1}$, \\ I NYOMAN GIRI PUTRA ${ }^{3}$, I GUSTI RICCA MAHATMA PUTRI ${ }^{1}$, ENEX YUNI ARTININGSIH ${ }^{1}$, \\ M. DANIE AL-MALIK ${ }^{1}$, NI KADEK DITA CAHY ANI ${ }^{1}$, ANDRIANUS SEMBIRING ${ }^{1}$ \\ ${ }^{1}$ Biodiversitas Indonesia (BIONESIA). Jl. Tukad Balian No. 121, Denpasar 80226, Bali, Indonesia. Tel : +62-821-47130566, \\ vemail: putudianpertiwi@gmail.com \\ ${ }^{2}$ Universitas Nahdlatul Ulama Kalimantan Barat. J1. Parit Derabak, Sungai Raya, Kubu Raya 78122, West Kalimantan, Indonesia \\ ${ }^{3}$ Department of Marine Science, Faculty of Marine Science and Fisheries, Universitas Udayana. Jl. Raya Unud, Jimbaran, Badung 80361, Bali, Indonesia
}

Manuscript received: 17 March 2020. Revision accepted: 25 August 2020.

\begin{abstract}
Pertiwi NPD, Suhendro MD, Yusmalinda NLA, Putra ING, Putri IGRM, Artinigsih EY, Al-Malik MD, Cahyani NKD, Sembiring A. 2020. Forensic genetic case study: Species identification and traceability of sea turtle caught in illegal trade in Bali, Indonesia. Biodiversitas 21: 4276-4283. Although known as protected endangered species, sea turtle trade is still occurring, especially in Indonesia. Understanding the species and population origin of sea turtle being sold in the illegal market is crucial for its conservation, where it will reveal the traceability of sea turtle trade to its population origin in the management unit areas. Thus, genetic forensic has been used as a key investigating tool to help with this problem. In this research, we aim to identify the species and population origin of the sea turtle caught and traded in the illegal market in Bali. Of the 20 samples collected from confiscated sea turtle during illegal trade, by-catch, and a traditional restaurant serving sea turtle meat, 17 samples were successfully analyzed and identified using PCR (polymerase chain reaction) methods. The result identified 15 samples as a green sea turtle (Chelonia mydas), while two samples were olive ridley sea turtle (Lepidochelys olivacea). Mixed Stock Analysis (MSA) with Bayesian indicated that the green sea turtle caught in illegal trade in Bali is originated mostly from the rookeries populations in Berau (29.98\%), Terengganu (17.84\%), Sarawak (14.84\%), and Ashmore Reef (11.85\%). Meanwhile, 18 other locations only showed the MSA value below 2\%, including the locations of Penang and Perak, Vietnam, Perhentian, Redang, Pahang, Mersing, Sabah Turtle Island Park (TIP), Sipadan, Coral Sea, western New Caledonia, Commonwealth of the Northern Mariana Island and Guam, northern New Guinea, Gulf of Carpenteria, Scott Reef, West Java, North West Self, Cobourg Peninsula, Cocos Keeling Island. Therefore, the exploitation of sea turtle in Bali will impact the decline in the genetic diversity of sea turtles population Indonesia and adjacent locations. Monitoring and protection of sea turtle species in Bali have to be a high priority because Bali is known as the hub for sea turtle illegal trade, and the exploitation of sea turtle in Bali will have an impact on the sea turtle population in other locations.
\end{abstract}

Keywords: Bali, forensic, genetic, mixed stock analysis, sea turtle

\section{INTRODUCTION}

In 1990, Greenpeace reported more than 21,000 sea turtles were slaughtered in Bali (Barr, 2001). A decade later, in 1999, the Indonesian government regulation or Peraturan Pemerintah Nomor 7 Tahun 1999 was released prohibiting trading of all sea turtle species, products, and eggs. In 2000, Bali's governor allowed some exception to keep using sea turtles in some traditional ceremony by declared the Bali Governor Decree (Surat Keputusan Gubernur Bali No. 243/2000). In the year 2004-2008, there were 20-30 individuals of sea turtles reported to be used for ceremonies per year in Bali (Jensen, 2009). Furthermore, the act of sea turtle illegal trade continues to happen in Bali, with some local media reported seven cases of sea turtles smuggling occurred in 2019; consist of 56 living individuals and $280 \mathrm{~kg}$ of sea turtle meat.

Sea turtle trade in Indonesia is still occurring although these species have been protected by national regulation and listed in Appendix I of the Convention of the
International Trade in Endangered Species (CITES) (www.cites.org; Nijman 2012; Nijman 2015; Foran and Ray 2016). Despite attempts to save the sea turtle population, conservation practitioners were facing difficulties accumulating reliable data on species being traded in Indonesia. Mostly because many illegal transactions are in the form of a body part, eggs, and meat (Nijman and Nekaris 2014; Foran and Ray 2016), hence preventing taxonomical identification. Assessing the rate of which turtle species being smuggled, including location, place of origin and source of population, and traded in variety of forms (meats, carapace, eggs) is crucial for its conservation management.

Conserving migratory species like sea turtles is crucial to understanding key migratory linkages to develop appropriate conservation measures (Dethmers et al. 2010; Joseph et al. 2016). These species regularly travel hundreds or thousands of kilometers between breeding or nesting area and foraging ground (Seminoff et al. 2012). Foraging ground is where sea turtles reside during the nonbreeding 
season and migration as the movement between foraging areas (if more than one foraging area is used), or between foraging area and nesting area (Ceriani et al. 2012). Recent works have reported that each foraging ground seems to support multiple breeding populations (Dethmers et al. 2010; Nishizawa et al. 2018). Thus, habitat destruction at foraging ground may have an adverse effect on remote rookeries. Understanding this matter will help law enforcement and conservation managers protect the sustainability of sea turtle populations in its origin population (rookeries grounds) and conduct the preventing actions at the route of sea turtle illegal trade.

The forensic study has been used as a critical investigating tool to fight the wildlife illegal trafficking (Botzler 2014; Johnson et al. 2014; Staats et al. 2016). Wildlife DNA forensic is a branch of forensic sciences that focuses on the use of genetic material to answer questions related to legal situations and is mainly used to determine the species, population, relationship, or individual identity of the sample (Linacre and Tobe 2013; Arenas et al. 2017). This knowledge had been used extensively in wildlife investigation case, including species identification (Dalton and Kotze 2011; Kumar et al. 2014; Sembiring et al. 2015: Ewart et al. 2018), identification of geographic origin (Ogden and Linacre 2015: Kumar et al. 2016), individual identification (Singh et al. 2015) and familial identification (Mucci et al. 2014; Bylemans et al. 2016).

With the depletion number of sea turtle population due to the illegal capture and black market trade (Quinones et al. 2017; Barrios-Garrido et al. 2017; Barrios-Garrido et al. 2020), there were several acts to fight this issue. Several studies have been done to understand the biological and ecological properties of sea turtle (Casale et al. 2010; Fuentes et al. 2011; Wyneken et al. 2013; Wiadnyana and Nastiti 2015). Another study used scientific tools to investigate the legal situation of confiscated sea turtle and or its derivate products (Alacs et al. 2010; Foran and Ray 2016; Mohd Jani et al. 2020). One of the forensic questions that genetic tools can address is identifying the species being traded and assessing its traceability (Bylemans et al. 2016; Roden et al. 2017).

The study of sea turtle using molecular genetic approach including the stock, geographic pattern and population genetic have been studied extensively (Fitzsimmons and Limpus 2014; Shamblin et al. 2014; Duran et al. 2015; Roden et al. 2017), including in Indonesia (Cahyani et al. 2007) and proven to be one of the successful traceability methods to identify the origin of sea turtle spotted in Indonesia. Using a similar approach, this research focuses on the forensic investigation of sea turtle trade. It aims to identify the species and population origin of the sea turtle caught and traded in the illegal market in Bali, Indonesia.

\section{MATERIALS AND METHODS}

Sample collection was conducted in 2015 until 2018, with a total of 20 samples collected from several different regions in Bali, Indonesia including Serangan (Denpasar City), Ketewel (Gianyar District), Karangasem (Karangasem District), and Bukit Jimbaran (Badung District) (Figure 1).

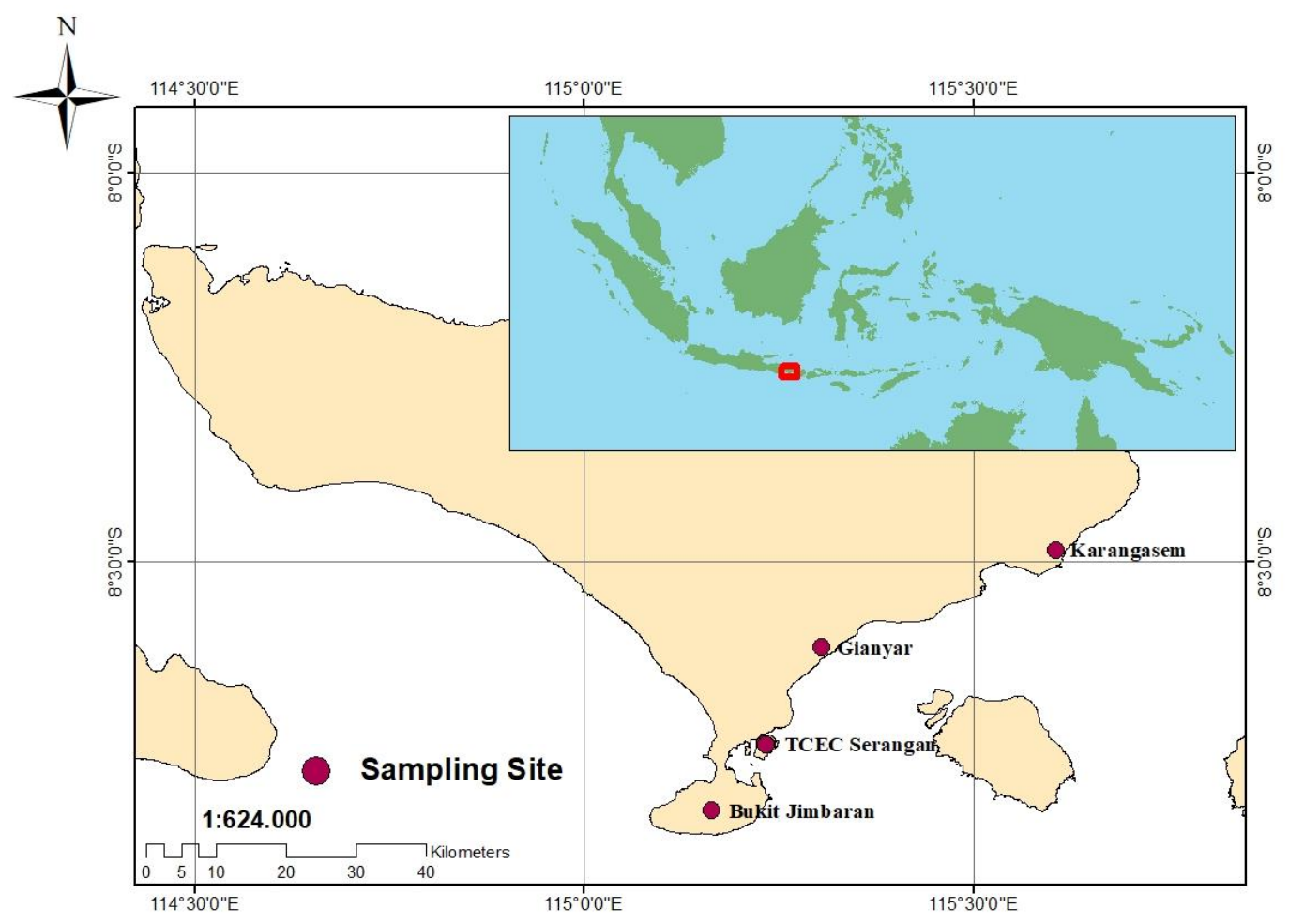

Figure 1. Map of sampling location in Bali, Indonesia including Serangan (Denpasar City), Ketewel (Gianyar District), Karangasem (Karangasem District), and Bukit Jimbaran (Badung District) 
The samples were in the form of meat and a tissue swab from cloaca. Eight (8) samples were collected from the living sea turtle that was caught by marine police during the illegal trade (BIO0201A01; BIO0201A02; BIO0202A01; BIO0202C01; BIO020701-04), while nine (9) samples were collected from by-catch using gillnet (BIO020801-05; BIO020901-02; BIO021101-02), and three (3) samples from traditional restaurant serving sea turtle meat (BIO021001; BIO021103; BIO021201).

Sample from Serangan-Denpasar was collected in the area of Turtle Conservation and Education Center (TCEC) from living sea turtle that confiscated by the marine police in the boat headed to Bali. In this TCEC facility, the sea turtle was treated and nurse before its ready to be released into the sea. Genetic samples of living sea turtle were collected from the cloaca tissue using the swab methods following the protocol used by Lanci et al. (2012), which briefly scrapping epidermal cells from the cloaca to obtain the DNA without harming the specimens. During this sampling activity, the sea turtle was also morphologically identify using its key features. All the living sea turtles collected were adult-size, however, we did not manage to record its CCL (curved carapace length) value.

By-catch samples were collected from fishermen near Serangan-Denpasar and Karangasem areas. Several areas in Bali and Java is known as the nesting site for some species of sea turtles, therefore it is common for fisherman in Bali to get sea turtle as by-catch product. As for the forensic identification of the illegal trade of sea turtle meat, we purchased the sea turtle meat in the form of dish known as "lawar penyu" in the areas of Bukit Jimbaran-Badung and Ketewel-Gianyar. This type of dish is not openly sold into the public.

Each sample collected were preserved in $95 \%$ ethanol and extracted using 10\% chelex solution (Walsh et al. 1991). The control region fragment of mitochondrial DNA (mtDNA) of approximately 817 bp length was amplified using polymerase chain reaction (PCR) with forward primer Ltei9 (5'-GGGAATAATCAAAAGAGAAGG-3') and reverse primer $\mathrm{H} 950$ (5' GTCTCGGATTTAGGGTTG-3') (Abreu-Grobois et al. 2006). The amplification method was run using the following standard parameter, including: denaturation of $94^{\circ} \mathrm{C}$ for $30 \mathrm{~s}$, annealing of $50^{\circ} \mathrm{C}$ for $30 \mathrm{~s}$, extension $72^{\circ} \mathrm{C}$ for $1 \mathrm{~min}$, repeated in 38 PCR cycles (Barber et al. 2006). PCR product was visualized via electrophoresis on $1 \%$ agarose gels stained with Biotium Mix. The successfully amplified products were then sequenced using Big Dye Chain Termination method.

The sequence was aligned using MEGA6 (Tamura et al. 2013). The species identity determined by comparing sequences to GenBank database (www.ncbi.nlm.nih.gov) enforcing homology threshold of $>99 \%$. Identification using phylogenetic tree was also reconstructed using Neighbor-Joining, p-distance method with 1000 bootstrap replication (Saitou \& Nei 1987; Kimura 1980). Included in this phylogenetic analysis were the sea turtle samples retrieved from GenBank with the accession number of
AB819806-AB819811 (Hamabata et al. 2014) and JX454979, JX454987, JX454991 (Duchene et al. 2012).

The green sea turtle identified samples were then compared with the haplotypes of green sea turtle from 31 management units in Pacific - Southeast Asia, identified by Nishizawa et al. (2018) and Jensen et al. (2016) ( \pm 801 bp sequence length). Identification of the original habitat of each sample were conducted using Mixed Stock Analysis (MSA) with BAYES program (Pella and Masuda 2001). Our haplotypes comparison were matched with 22 locations within 31 management units within Nishizawa et al. (2018) and Jensen et al. (2016) and used as candidate for origin populations. Therefore, we ran 22 Markov Chain Monte Carlo (MCMC) chains, and each chain began with $95 \%$ of all of the samples. Each chain contained 10,000 samples and the first 5,000 were discarded as burn-in steps. The convergence of MCMC sampling was assessed using Gelman-Rubin shrink factor (Gelman and Rubin, 1992), which indicates a lack of convergence if the value is greater than 1.2 .

\section{RESULTS AND DISCUSSION}

Mitochondrial (mtDNA) control region sequences were amplified from 17 out of 20 samples, with a length of 817 bp. Among all the samples collected, the live sea turtle has confirmed its species using both morphological characteristics and genetic. Meanwhile, for the sample in the form of meat and traditional dishes, species identification was confirmed using genetic methods by comparing the sequence into the genetic database and constructing the samples' phylogenetic tree. The species identification using a phylogenetic tree (Figure 2) and BLAST (Table 1) shown that 15 samples were identified as Chelonia mydas (green sea turtle), and two samples were identified as Lepidochelys olivacea (olive ridley sea turtle). Genetic distance value within species and between species was $0-0.016$ and 0.148 , respectively. Meanwhile, the BLAST result, which comparing samples with the GenBank database (www.ncbi.nlm.nih.gov), indicated very high similarity between samples and databases, with the percentage of identification value of $99-100 \%$.

From 15 samples identified as $C$. mydas, nine different haplotypes were found with the haplotype diversity value of 0.9143 and nucleotide diversity value of 0.01134 . MSA analysis was conducted for only the green sea turtles $(C$. mydas) samples, using a comparison with the haplotypes from Nishizawa et al. (2018) and Jensen et al. (2016). Our haplotype comparison with the previous studies showed 7 similar haplotypes (CmP49.1; CmP57.2; CmP87.1; CmP40.1; CmP75.1; CmP83.1; CmP88.1) and 2 new haplotypes (orphan).

The mixed stock analysis compared with 31 management units used in Nishizawa et al. (2018) and Jensen et al. (2016) showed that our $C$. mydas haplotypes were related to 22 of its management units location within Pacific - Southeast Asia region. Among those 22 locations, the MSA result indicated that our samples were originated 
mostly from Berau (29.98\%), Terengganu (17.84\%), Sarawak (14.84\%), and Ashmore Reef (11.85\%). Meanwhile, 18 other locations only showed the MSA value below 2\%, including the locations of Penang and Perak, Vietnam, Perhentian, Redang, Pahang, Mersing, Sabah Turtle Island Park (TIP), Sipadan, Coral Sea, western New
Caledonia, Commonwealth of the Northern Mariana Island and Guam, northern New Guinea, Gulf of Carpenteria, Scott Reef, West Java, North West Self, Cobourg Peninsula, Cocos Keeling Island (Figure 3). In Figure 3.B, also showed the 31 Management Units area as the sources in mixed stock analysis referring to Nishizawa et al. (2018).

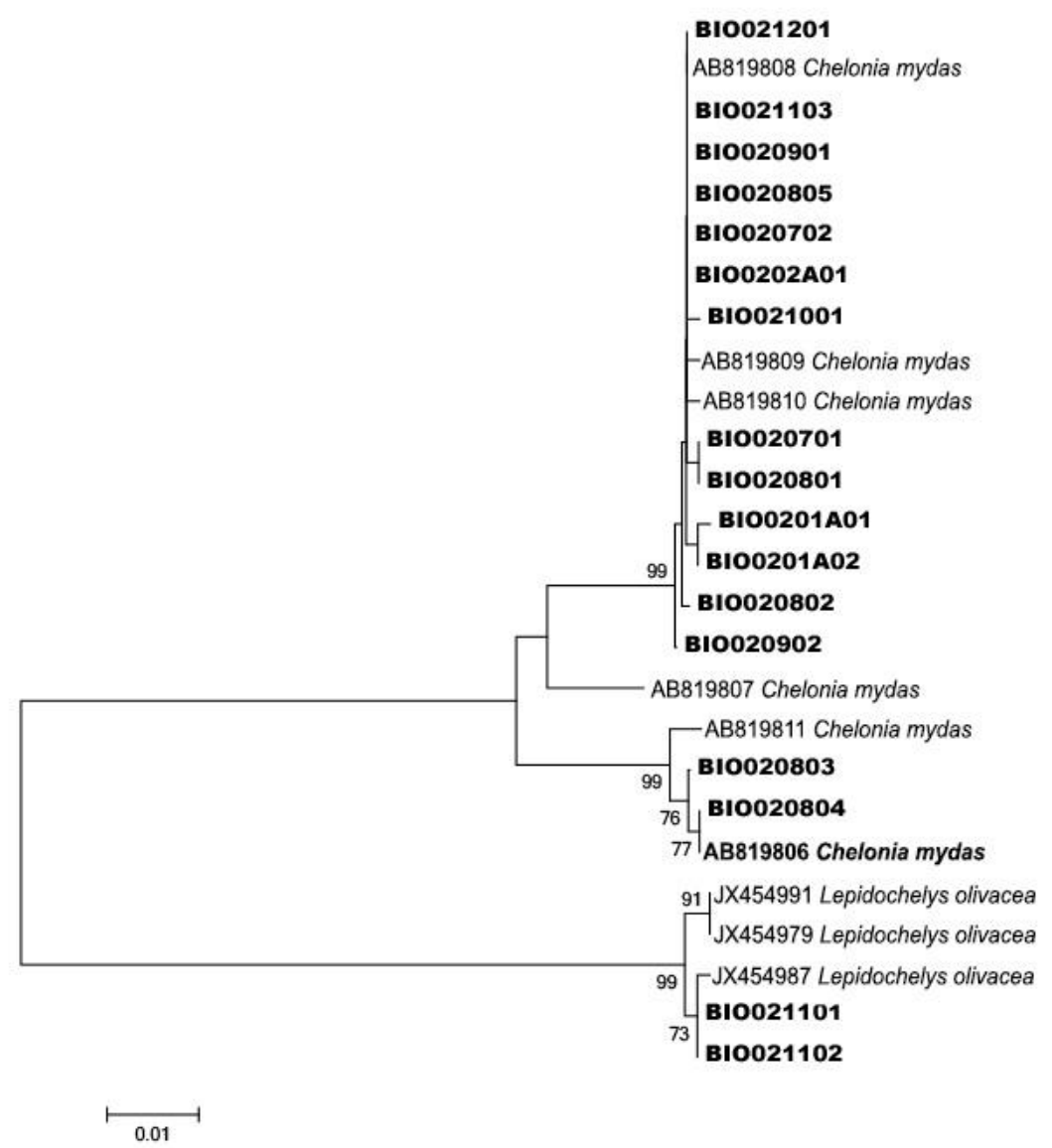

Figure 2. Phylogenetic tree of sea turtle identification comparing with Genbank data, using Neighbor-joining, p-distance method with 1000 bootstrap

Table 1. Identification result using BLAST method

\begin{tabular}{cccccc}
\hline ID & Type of samples & BLAST result & BLAST score & Query cover $(\%)$ & Ident $(\%)$ \\
\hline BIO0201A01 & Living sea turtle caught by marine police & Chelonia mydas & 1467 & 100 & 99.63 \\
BIO0201A02 & Living sea turtle caught by marine police & Chelonia mydas & 1406 & 100 & 99.61 \\
BIO0202A01 & Living sea turtle caught by marine police & Chelonia mydas & 1478 & 100 & 100 \\
BIO020701 & Living sea turtle caught by marine police & Chelonia mydas & 1563 & 99 & 99.53 \\
BIO020702 & Living sea turtle caught by marine police & Chelonia mydas & 1546 & 100 & 99.53 \\
BIO020801 & Meat from by-catch & Chelonia mydas & 1559 & 100 & 99.53 \\
BIO020802 & Meat from by-catch & Chelonia mydas & 1555 & 100 & 98.89 \\
BIO020803 & Meat from by-catch & Chelonia mydas & 1447 & 100 & 99.18 \\
BIO020804 & Meat from by-catch & Chelonia mydas & 1537 & 100 & 99.42 \\
BIO020805 & Meat from by-catch & Chelonia mydas & 1554 & 100 & 99.42 \\
BIO020901 & Meat from by-catch & Chelonia mydas & 1554 & 100 & 99.53 \\
BIO020902 & Meat from by-catch & Chelonia mydas & 1554 & 1544 & 100 \\
BIO021001 & Meat from traditional restaurant & Chelonia mydas & 1489 & 99.18 \\
BIO021101 & Meat from by-catch & Lepidochelys olivacea & 1576 & 100 \\
BIO021102 & Meat from by-catch & Lepidochelys olivacea & 1546 & 100 \\
BIO021103 & Meat from traditional restaurant & Chelonia mydas & 1554 & 99.75 \\
BIO021201 & Meat from traditional restaurant & Chelonia mydas & 99.88 \\
\hline
\end{tabular}




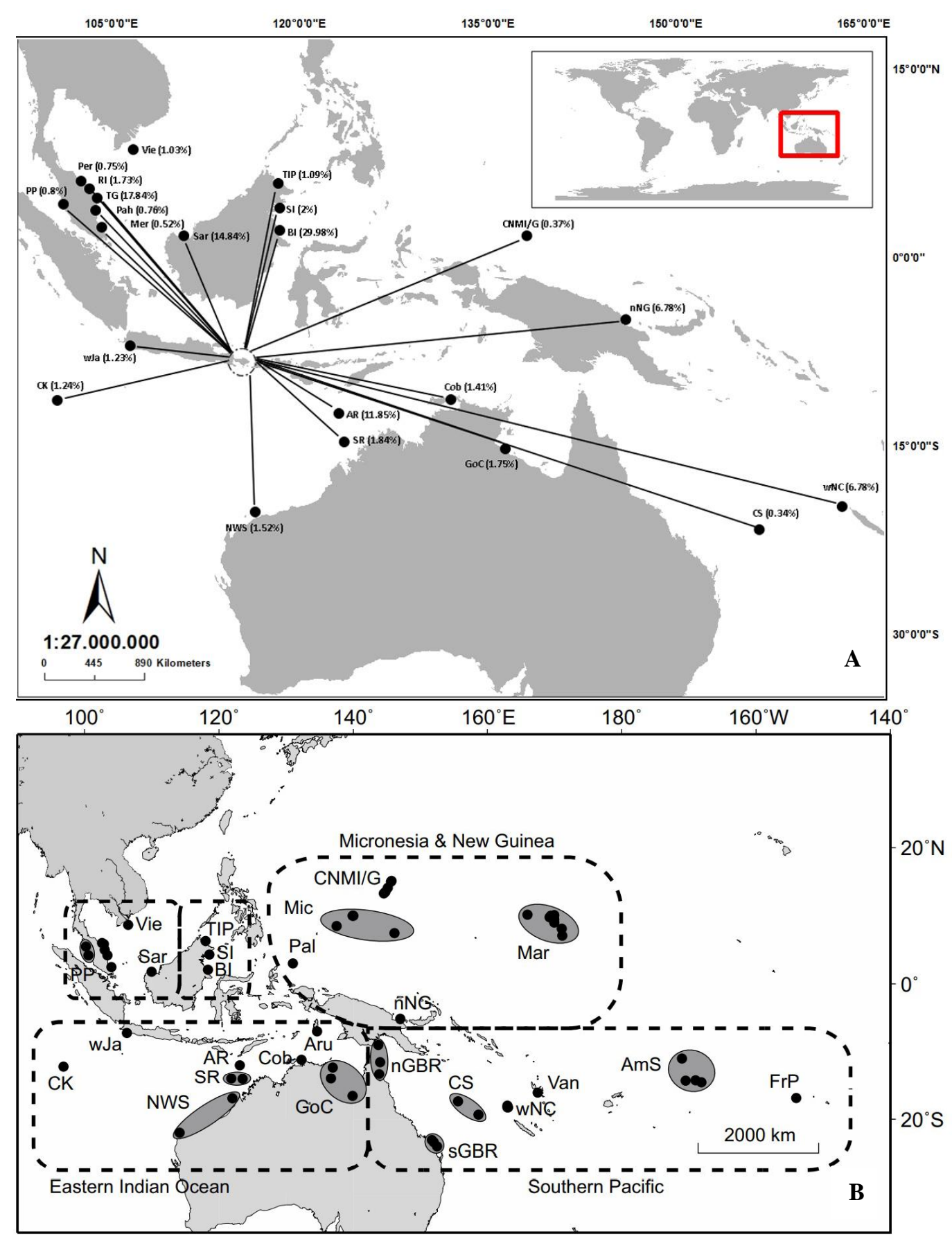

Figure 3. (a) Nesting origin population result from the C. mydas samples collected in Bali using Mixed Stock Analysis. (b) 31 Management Units (Mus) as sources in mixed stock analysis (Nishizawa et al. 2018). Dashed lines indicate regional grouping of Mus. Abbreviations undefined in the text and figure are as follows: PP Penang and Perak, $B I$ Berau, $n G B R$ northern Great Barrier Reef, $C S$ Coral Sea, $s G B R$ southern Great Barrier Reef, $w N C$ western New Caledonia, $n N G$ northern New Guinea, Van Vanuatu, Mic Micronesia, Mar Marshall Islands, Pal Palau, CNMI/G Commonwealth of the Northern Mariana Islands and Guam, AmS American Samoa, FrP French Polynesia, GoC Gulf of Carpenteria, AR Ashmore Reef, SR Scott Reef, wJa west Java, NWS North West Shelf, Cob Cobourg Peninsula, $C K$ Cocos "Keeling Island, Vie Vietnam, Per Perhentian, RI Redang Island, TG Terengganu, Pah Pahang, Mer Mersing, Sar Sarawak, TIP Sabah Turtle Island Park, SI Sipadan

Most of the sea turtles species listed in Appendix I of the Convention of the International Trade in Endangered Species (CITES) (www.cites.org; Foran and Ray 2016) have also been regulated in the Indonesian government regulation. In the Indonesian law or Peraturan Pemerintah Nomor 7 Tahun 1999 and Undang Undang No. 50 Tahun
1990, all of the sea turtle species, products, and eggs were prohibited trading. The Bali's local regulation also supported this law through Bali Governor Decree (Surat Keputusan Gubernur Bali Nomor 243/2000) prohibiting the sea turtle trading. On the other hand, this regulation still giving the exception only for some traditional ceremony 
that has been allowed by the local authority (Ario et al. 2016). In contrast with this regulation, based on our sample collection from 2015 - 2018, sea turtle illegal trade still happened in Bali, with the species being traded in Chelonia mydas (green sea turtle) and Lepidochelys olivacea (olive ridley sea turtle). Species identification indicates a high similarity (99.18-100\%) between samples DNA sequences with the genetic database (BLAST GenBank). Phylogenetic analysis also showed low genetic distance within the similar species, which indicated that the genetic methods accurately identify the species of the samples collected.

The illegal trade of sea turtle in Bali collected in this study, including the live animals confiscated by the Indonesian marine police during its shipping from East Java to Bali, turtle meat served at a traditional restaurant, and fisheries by-catch. Among all 20 samples collected, $40 \%$ were from the sea turtle that was smuggled from Java to Bali, which was the living sea turtle samples. $45 \%$ of the samples were by-catch products, and the other $15 \%$ were illegal sea turtle food products. Sea turtle by-catch was usually caught from pelagic longline fishing (Casale et al. 2010), bottom trawlers, and set nets by small-scale fisheries (Casale 2011; Barrios-Garrido et al. 2020). The sea turtle caught by this practice has been used as the food source for many years by the local community (Tapilatu et al. 2017). Lack of information to the traditional local fisherman on the importance of sea turtle might be one of the causes of the high number of sea turtle by-catch. This issue can be overcome by increasing the environmental education strategies and information distribution on the importance of sea turtle and how to handle by-catch sea turtle and improve the new technology on fishing gear, which can help reduce the turtle by-catch (Casale 2011).

Meanwhile, from our investigation of several traditional restaurants, it is confirmed that some of them were serving sea turtle meat, despite the restriction of selling this type of meat as a food. Bali Governor Decree's use of sea turtle meat for ceremonial purposes in Bali has also been regulated (Keputusan Gubernur Bali No. 243/2000). Since then, the use of sea turtle meat for various types of ceremonies in Bali has been substituted with duck or other animal meat (Sudiana 2010). Among the genetically identified samples, $75 \%$ were identified as $C$. mydas (green sea turtles), $10 \%$ were identified as L. olivacea (olive ridley sea turtle), while $15 \%$ were unidentified samples. The unidentified samples can be caused by the poor condition of the sample preservation, thus lead to the low quantity and quality of the DNA. However, the specimen's DNA was managed to amplify the tissue samples collected from the cloaca using the swab methods and the food product of a traditional restaurant (known as "lawar"). The result indicated that the swab methods could be used to collect the DNA of living organisms without harming the specimens, especially for the protected species. These methods have also previously successful in being used as a method in studying sea turtle in other areas (Stephen et al. 2010; Al-Bahry et al. 2011; Lanci et al. 2012; TorresRodriguez et al. 2017).

Chelonia mydas and L. olivacea are known as two out of six sea turtle species commonly found to nest and migrate throughout Indonesian water (Maulany et al. 2012; Bara et al. 2013; Heithaus et al. 2014). All sea turtle species, especially $C$. mydas and L. olivacea, are vulnerable to population decline during all of its life-stages. An anthropogenic threat such as eggs poaching and illegal trade of adult sea turtle for accessories and food is also the most contributing factors that impact the declining number of sea turtle populations (Nijman and Nekaris 2014; Migraine 2015). The genetic diversity of sea turtle species (haplotypes) around the world were shown the uniqueness of particular regions or populations (Dethmers et al. 2006). For example, the Indo-Pacific ecoregion holds several different nesting and foraging sites characterized by different haplotypes diversity (Nishizawa et al. 2018); Jensen et al.2016). Two new haplotypes (orphan) found in this study, indicate the high diversity of sea turtle haplotype still needed to be recorded. Future study is required to collect information regarding the orphan haplotypes and how it gives us more insight into the sea turtle population in Indonesia.

Mixed Stock Analyses with the Bayesian approach for the green sea turtle indicate five rookeries that have the highest contribution for sea turtle haplotype collected in Bali. The origin rookeries including Berau (29.98\%), Terengganu (17.84\%), Sarawak (14.84\%), and Ashmore Reef $(11.85 \%)$. Thus result indicated that the sea turtle sample collected in Bali has similar genetic characteristics with several stocks from around Indo-Pacific rookeries. Berau, East Kalimantan, reported being the highest contributor for the individual illegally traded in Bali. This is not surprising since Berau is known to be one of the most significant nesting sites and foraging ground for the sea turtle population in Indonesia (Adnyana et al. 2008; Dharmadi and Wiadnyana 2008). The fact that Berau, Terengganu, and Sarawak contributed more than $10 \%$ of the sea turtle traded in Bali showed that those areas are important for sea turtle population' nesting and foraging areas across Indo-Pacific (Joseph et al. 2014; Nishizawa et al. 2018).

The connectivity between different sea turtle populations is also explained by the sea turtle natural behavior to travel across the ocean. Adult sea turtle undertakes a long-distance migration between the nesting site and foraging ground during their breeding season. Satellite telemetry study found this migration sometimes takes over $7,000 \mathrm{~km}$ during a one-month duration (Pilcher et al. 2020). This transoceanic migration leads the organism to swim from one country to another. The contribution of Ashmore reef in Australia showed how wide the possible area use by the illegal trader caught the sea turtle.

The broad representation from several stocks of the population also indicated that the sea turtle traded in Bali could originate from other locations within and outside of Indonesia. Therefore, sea turtle protection needs to be done as a complete management area within Indonesian and other surrounding locations, especially for the places that have been known as a breeding and feeding ground of the sea turtle species. This study also supports the importance of multi-region conservation efforts for sea turtle, as explained by the Management Units (Gomez and 
Khrisnasamy 2019). The management unit is an area with genetic similarity showing the migratory connectivity of sea turtle populations between the area (Dethmers et al 2006; Jensen et al. 2016; Nishizawa et al. 2018). This connectivity between nesting and foraging areas demonstrated the importance of a comprehensive management plan between rookeries because the threat in one rookie will impact the adjacent rookeries.

In conclusion, the sea turtle samples collected from the illegal trade in Bali were identified as the species of Chelonia mydas (green sea turtle) and Lepidochelys olivacea (Olive Ridley sea turtle). This finding also becomes one of the evidence that the illegal trade of sea turtle is still happening in Bali, and should be a wake-up call to the Indonesian Government. Monitoring and protection of sea turtle species in Bali have to be a high priority because Bali is known as the hub for sea turtle illegal trade, and the exploitation of sea turtle in Bali will have an impact on the sea turtle population in other locations.

\section{ACKNOWLEDGEMENTS}

We gratefully acknowledge Rufford Foundation (Small Grant Ref: 22043-1) for their financial support on this project. We also thank Turtle Conservation and Education Center (TCEC), Serangan for their help in sample collection. Paul Barber, Ida Astarini, and Dwi Suprapti for their guidance and advice. Udayana University, Diponegoro Marine Biodiversity Team, and WWF Indonesia for their support in this project.

\section{REFERENCES}

Abreu-Grobois FA, Horrocks JA, Formia A, Leroux R, Velez-Zuazo X, Soares L, Meylan P..2006. New mtDNA D-loop primers which work for a variety of marine turtle species may increase the resolution of mixed stock analysis. In: Frick M, Panagopoulous A, Rees A, Williem K (eds.). 16th Annual Symposium on Sea Turtle Biology and Conservation. Athens, Greek.

Adnyana W, Soede LP, Gearheart G, Halim M. 2008. Status of green turtle (Chelonia mydas) nesting and foraging populations of Berau, East Kalimantan, Indonesia, including results from tagging and telemetry. Indian Ocean Turtle Newslett 7: 1-11.

Al-Bahry SN, Mahmoud IY, Al-Zadjali M, Elshafie A, Al-Harthy A, AlAlawi W. 2011. Antibiotic-resistant bacteria as bio-indicator of polluted effluent in the green turtles, Chelonia mydas in Oman. Marine Environ Res 71 (2): 139-144. DOI 10.1016/j.marenvres.2010.12.005

Alacs EA, Georges A, Fitzsimmons NN, Robertson J. 2010. DNA detective: a review of molecular approaches to wildlife forensics. Forensic Sci Med Pathol 6 (3): 180-194. DOI: 10.1007/s12024-0099131-7.

Arenas M, Pereira F, Oliveira M, Pinto N, Lopes AM, Gomes V, Carracedo A, Amorim A. 2017. Forensic genetics and genomics: Much more than just a human affair. PLoS Genet 13 (9): e1006960. DOI: 10.1371/journal.pgen.1006960.

Ario R, Wibowo E, Pratikto I, Fajar S. 2016. Pelestarian habitat penyu dari ancaman kepunahan di Turtle Conservation and Education Center (TCEC), Bali. Jurnal Kelautan Tropis 19 (1): 60-66. [Indonesian]

Bara DA, Redjeki S, Hariadi. 2013. Studi Habitat Penelusuran Penyu Hijau (Chelonia mydas) di Pantai Pangumbahan Sukabumi Jawa Barat. J Mar Res 2 (3): 147-155.
Barber PH, Erdmann MV, Palumbi SR. 2006. Comparative phylogeography of three codistributed stomatopods: Origins and timing of regional lineage diversification in the Coral Triangle. Evolution $60 \quad$ (9): $1825-1839$. DOI: $10.1111 /$ j.00143820.2006.tb00526.x.

Barr C. 2001. Current Status of Trade and Legal Protection for Sea Turtles in Indonesia. Marine Turtles Newslett 54: 4-7

Barrios-Garrido HA, Espinoza-Rodriguez N, Rojas-Canizales D, Palmar J, Wildermann N, Montiel-Villalobos MG, Hamann M. 2017. Trade of marine turtles along the Southwestern Coast of the Gulf of Venezuela. Mar Biodiv Rec 10 (1): 1-12. DOI: 10.1186/s41200-017-0115-0.

Barrios-Garrido HA, Montiel-Villalobos MG, Palmar J, Rodriguez-Clark KM. 2020. Wayuu capture of green turtles, Chelonia mydas, in the Gulf of Venezuela: A major Caribbean artisanal turtle fishery. Ocean Coast Manag 188: 105123. DOI: 10.1016/j.ocecoaman. 2020.105123.

Botzler R. 2014. Book Review: Wildlife forensic investigation principles and practice. J Wildlife Dis 50 (1): 154-157.

Bylemans J, Maes GE, Diopere E, Cariani A, Senn H, Taylor MI, Heylar S, Bargelloni L, Bonaldo A, Carvalho G, Guarniero I, Komen H, Martinsohn JT, Nielsen EE, Tinti F, Volckaert FAM, Ogden R. 2016. Evaluating genetic traceability methods for captive-bred marine fish and their application in fisheries management and wildlife forensics. Aquac Environ Interact 8: 131-145. DOI: 10.3354/aei00164

Cahyani NKD, Adnyana IBW, Arthana IW. 2007. Identifikasi Jejaring Pengelolaan Konservasi Penyu Hijau (Chelonia mydas) melalui Penentuan Komposisi Genetik dan Metal Tag di Laut Sulu, Sulawesi. Ecotrophic 2 (2): 1-7.

Casale P, Affronte M, Insacco G, Freggi D, Vallini C, D'astore PP, Basso R, Paolillo G, Abbate G, Argano R. 2010. Sea Turtle Stranding Reveal High Antrophogenic Mortality in Italian Waters. Aquatic Conserv Mar Freshw Ecosyst 20 (6): 611-620. DOI: 10.1002/aqc. 1133

Casale P. 2011. Sea turtle by-catch in the Mediterranean. Fish Fish 12 (3): 299-316. DOI: 10.1111/j.1467-2979.2010.00394.x

Ceriani SA, Roth JD, Evans DR, Weishampel JF, Ehrhart LM. 2012. Inferring Foraging Areas of Nesting Loggerhead Turtles Using Satellite Telemetry and Stable Isotopes. PLoS ONE 7 (9). DOI: 10.1371/journal.pone.0045335

Dalton DL, Kotze A. 2011. DNA Barcoding as A Tool for Species Identification in Three Forensic Wildlife Cases in South Africa. Forensic Sci Intl 207: e51-e54. DOI: 10.1016/j.forsciint.2010.12.017.

Dethmers KEM, Broderick D, Morotz C, Fitzsimmons NN, Limpus CJ, Lavery S, Whitting S, Guinea M, Prince RIT, Kennet R. 2006. The Genetic Structure of Australasian green turtles (Chelonia mydas): exploring the geographical scale of genetic exchange. Mol Ecol 15 (13): 3931-3946. DOI: 10.1111/j.1365-294X.2006.03070.x.

Dethmers KEM, Jensen MP, Fitzsimmons NN, Broderick DA, Limpus CJ, Moritz C. 2010. Migration of green turtles (Chelonia mydas) from Australasian feeding grounds inferred from genetic analyses. Mar Freshw Res 61 (12): 1376-1387. DOI: 10.1071/MF10084.

Dharmadi, Wiadnyana NN. 2008. Kondisi habitat dan kaitannya dengan jumlah penyu hijau (Chelonia mydas) yang bersarang di Pulau Derawan, Berau-Kalimantan Timur. Jurnal Penelitian Perikanan Indonesia 1 4(2): 195-204. [Indonesian]

Duchene S, A Frey, A Alfaro-Nunez, PH Dutton, M Thomas, P Gilbert, PA Morin. 2012. Marine turtle mitogenome phylogenetics and evolution. Mol Phylogenet Evol 65 (1): 241-250.

Duran N, Dunbar SG, Escobar-III RA, Standish TG. 2015. High frequency of multiple paternity in a solitary population of olive ridley sea turtle in Honduras. J Exp Mar Biol Ecol 463: 63-71. DOI: 10.1016/j.jembe.2014.10.023

Ewart KM, Frankham GJ, McEwing R, Webster LCMI, Ciavaglia SA, Linacre AMT, The DT, Ovouthan K, Johnson RN. 2018. An internationally standardized species identification test for use on suspected seized rhinoceros horn in the illegal wildlife trade. Forensic Sci Intl Genet 32: 33-39. DOI: 10.1016/j.fsigen.2017.10.003.

Fitzsimmons NN, Limpus CJ. 2014. Marine turtle genetic stocks of the Indo-Pacific: identifying boundaries and knowledge gaps. Indian Ocean Turtle Newslett 20: 2-18.

Foran DR, Ray RL. 2016. Mitochondrial DNA profiling of illegal tortoiseshell products derived from Hawksbill Sea Turtles. J Forensic Sci 61 (4): 1062-1066. DOI: 10.1111/1556-4029.13062.

Fuentes MMPB, Limpus CJ, Hamann N. 2011. Vulnerability of sea turtle nesting grounds to climate change. Global Ch Biol 17 (1): 140-153. DOI: $10.1111 / \mathrm{j} .1365-2486.2010 .02192 . x$. 
Gelman A, Rubin DB. 1992. Inference from iterative simulation using multiple sequences. Statistical Sci 7: 457-511.

Gomez L, Krishnasamy K. 2019. A rapid assessment on the trade-in marine turtles in Indonesia, Malaysia and Viet Nam. TRAFFIC. Petaling Jaya, Malaysia.

Hamabata T, Kamezaki N, Hikida T. 2014. Genetic structure of Green Turtle (Chelonia mydas) peripheral populations nesting in the Northwestern Pacific rookeries: evidence for northern refugia and postglacial colonization. Mar Biol 161: 495-507. DOI: 10.1007/s00227-013-2352-z

Heithaus MR, Alcoverro T, Arthur R, Burkholder DA, Coates KA, Christianen MJA, Kelkar N, Manuel SA, Wirsing AJ, Kenworthy WJ, Fourqurean JW. 2014. Seagrass in the age of sea turtle conservation and shark overfishing. Front Mar Sci 1 (28): 1-6. DOI: 10.3389/fmars.2014.00028

Jensen A. 2009. Shifting Focus: Redefining the Goals of Sea Turtle Consumption and Protection in Bali. Independent Study Project (ISP) Collection. https: //digitalcollections.sit.edu/isp collection/753

Jensen MP, Bell I, Limpus CJ, Hammann M, Ambar S, Whap T, David C, Fitzsimmons NN. 2016. Spatial and temporal genetic variation among size classes of green turtles (Chelonia mydas) provides information on oceanic dispersal and population dynamics. Mar Ecol Progr Ser 543: 241-256. DOI: $10.3354 / \mathrm{meps} 11521$

Johnson RN, Wilson-Wilde L, Linacre A. 2014. Current and future directions of DNA in wildlife forensic science. Forensic Sci Int Genet 10: 1-11. DOI: 10.1016/j.fsigen.2013.12.007

Joseph J, Kuen CY, Palaniappan PM, Chark LH. 2014. Genetic investigation of green turtles (Chelonia mydas) harvested from a foraging ground at Mantanani, Sabah, Malaysia. Herpetological Conserv Biol 9 (3): 516-523.

Joseph, J, Kadir SAS, Nishizawa H, Arshaad WM, Jamaludin NA, Jaaman SA, Bali J, Katoh M. 2016. Genetic stock compositions and nata origin of green turtle (Chelonia mydas) foraging at Brunei Bay. Global Ecol Conserv 6: 16-24. DOI: 10.1016/j.gecco.2016.01.003

Kimura M. 1980. A simple method for estimating evolutionary rates of base substitutions through comparative studies of nucleotide sequences. J Mol Evol 16(2): 111-120. DOI: 10.1007/BF01731581

Kumar VP, Kumar D, Goyal SP. 2014. Wildlife DNA forensic in curbing illegal wildlife trade: species identification from seizures. Intl J Forensic Sci Pathol 2(5): 38-42. DOI: 10.19070/2332-287X-1400012

Kumar VP, Shrivastwa A, Nigam P, Kumar D, Goyal SP. 2016. Genetic characterization of wild swamp deer populations: ex-situ conservation and forensics implications. Mitochondrial DNA Part A 28 (6): 965970. DOI: $10.1080 / 24701394.2016 .1225732$

Lanci AK, Roden SE, Bowman A, LaCasella EL, Frey A, Dutton PH 2012. Evaluating buccal and cloacal swabs for ease of collection and use in genetic analyses of marine turtles. Chelonian Conserv Biol 11 (1): 144-148. DOI: $10.2744 / C C B-0950.1$

Linacre AMT, Tobe SS. 2013. Wildlife DNA Analysis: Applications in Forensic Science. Wiley-Blackwell, UK.

Maulany RI, Booth DT, Baxter GS. 2012. The Effect of Incubation Temperature on Hatchling Quality in the Olive Ridley Turtle, Lepidochelys olivacea, from Alas Purwo National Park, East Java, Indonesia: Implications for Hatchery Management. Mar Biol 159 2561-2661. DOI: 10.1007/s00227-012-2022-6

Migraine P. 2015. Report on illegal take and trade of marine turtles in the Indian Ocean Region. Mar Turtle Newslett 145: 27-28.

Mohd-Jani J, Jamalludin MA, Long SL. 2020. To Ban or Not to Ban? Reviewing an Ongoing Dilemma on Sea Turtle Egg Trade in Terengganu, Malaysia. Front Mar Sci 6: 762. DOI 10.3389/fmars.2019.00762

Mucci N, Mengoni C, Randi E. 2014. Wildlife DNA forensic against crime: resolution of a tortoise theft. Forensic Sci Intl Genet 8 (1): 200-202. DOI: 10.1016/j.fsigen.2013.10.001

Nijman V. 2012. Marine turtles trade at Pangandaran, South Java TRAFFIC Bull 24: 49-50.

Nijman V, Nekaris KAI. 2014. Trade in wildlife in Bali, Indonesia, for medicinal and decorative purposes. TRAFFIC Bull 26 (1): 31-36.

Nijman V. 2015. Decades-long open trade in protected marine turtles along Java's South Coast. Mar Turtle Newslett 144: 10-11.

Nishizawa H, Joseph J, Chong YK, Kadir YAS, Isnain I, Ganyai TA, Jaaman S, Zhang X. 2018. Comparison of the rookery connectivity and migratory connectivity: insight into movement and colonization of the green turtle (Chelonia mydas) in Pacific-Southeast Asia. Mar Biol 165: 77. DOI: 10.1007/s00227-018-3328-9
Ogden R, Linacre A. 2015. Wildlife forensic science: A review of genetic geographic origin assignment. Forensic Sci Int Genet 18: 1 52-159. DOI: 10.1016/j.fsigen.2015.02.008

Pella JJ, Masuda M. 2001. Bayesian methods for analysis of stock mixtures from genetic characters. Fish Bull 99: 151-167.

Pilcher NJ, Rodriguez-Zarate CJ, Antonopoulou MA, Mateos-Molina D, Das HS, Bugla IA. 2020. Combining laparoscopy and satellite tracking: Successful round-trip tracking of female green turtles from feeding areas to nesting grounds and back. Glob Ecol Conserv 23. DOI: 10.1016/j.gecco.2020.e01169

Quinones J, Quispe S, Galindo O. 2017. Illegal capture and black market trade of sea turtles in Pisco, Peru: the never-ending story. Latin American J Aquat Res 45 (3): 615-621. DOI: 10.3856/vol45-issue3fulltext-11

Roden SE, Stewart KR, James MC, Dodge, KL Amicos FD, Dutton PH. 2017. Genetic fingerprinting reveals natal origins of male leatherback turtles encountered in the Atlantic Ocean and Mediterranean Sea. Mar Biol 164 (9): 181. DOI: 10.1007/s00227-017-3211-0

Saitou N, Nei M. 1987. The neighbor-joining method: a new method for reconstructing phylogenetic tree. Mol Biol Evol 4 (4): 406-425. DOI: 10.1093/oxfordjournals.molbev.a040454

Sembiring A, Pertiwi NPD, Mahardini A, Wulandari R, Kurniasih EM, Kuncoro AW, Cahyani NK, Anggoro AW, Ulfa M, Madduppa H, Carpenter KE, Barber PH, Mahardika GN. 2015. DNA Barcoding reveals targeted fisheries for endangered sharks in Indonesia. Fish Res 164: 130-134. DOI: 10.1016/j.fishres.2014.11.003

Seminoff JA, Benson SR, Arthur KE, Eguchi T, Dutton PH, Tapilatu RF, Popp BN. 2012. Stable Isotope Tracking of Endangered Sea Turtles: Validation with Satellite Telemetry and $\delta^{15} \mathrm{~N}$ Analysis of Amino Acids. PLoS ONE 7(5): e37403. DOI: 10.1371/journal.pone.0037403

Shamblin BM, BoltenAB, Abreu-Grobois FA, Bjorndal KA, Cardona L, Carreras C, Clausa M, Monzon-Arguello C, Nairn CJ, Nielsen JT, Nel R, Soares LS, Stewart KR, Vilaca ST, Turkoza O, Yilmaz C, Dutton PH. 2014. Geographic patterns of genetic variation in a broadly distributed marine vertebrate: new insights into loggerhead turtle stock structure from expanded mitochondrial DNA sequences. PloS One 9 (1): e0085956. DOI: 10.1371/journal.pone.0085956

Singh SK, Vipin, Mishra S, Pandey P, Kumar VP, Goyal SP. 2015. Understanding Human-Tiger Conflict around Corbett Tiger Reserve India: A Case Study Using Forensic Genetics. Wildlife Biol Pract 11 (1): 1-11.

Staats M, Arulandhu AJ, Gravendeel B, Holst-Jensen A, Scholtens I, Peelen T, Prins TW, Kook E. 2016. Advances in DNA Barcoding for food and wildlife forensic species identification. Anal Bioanal Chem 408 (17): 4615-4630. DOI: 10.1007/s00216-016-9595-8.

Stephens SH, White VC, Bremer JRA. 2010. Assessment of genetic tissue sampling methods for the critically endangered Kemp's Ridley Sea Turtle (Lepidochelys kempii). Mar Turtle Newslett 128: 19.

Sudiana IGN. 2010. Transformasi budaya masyarakat Desa Serangan di Denpasar Selatan dalam pelestarian satwa penyu. Jurnal Bumi Lestari 10 (2): 311-320.

Tapilatu RF, Wona H, Batubara PP. 2017. Status of sea turtle populations and its conservation at Bird's Head Seascape, Western Papua, Indonesia. Biodiversitas 18 (1): 12-136. DOI: 10.13057/biodiv/d180118

Tamura K, Stecher G, Peterson D, Filipski A, Kumar S. 2013. MEGA6: Molecular Evolutionary Genetics Analysis version 6.0. Mol Biol Evol 30 (12): 2725-2729.

The Convention on International Trade in Endangered Species of Wild Fauna and Flora. www.cites.org.

Torres-Rodríguez JA, Hernández-Rivera LJ, Bernal-Gutiérrez J, PabónAldana K, Jauregui-Romero AG, Lecompte-Pérez PO. 2017. Successful use of buccal swabs to obtain genetic material from Loggerhead Sea Turtles (Caretta caretta). Mar Turtle Newslett 153: 1-4.

Walsh PS, Metzger DA, Higuchi R. 1991. Chelex 100 as a medium for simple extraction of DNA for PCR-based typing from forensic material. BioTechniq 10 (4): 506-513.

Wiadnyana NN, Nastiti AS. 2015. Impact of turtle conservation development on the socio-economy of coastal communities and the number of nesting turtles: a case study of Pangumbahan Beach, Sukabumi Regency, West Java, Indonesia. Proceedings of the Design Symposium on Conservation Ecosystem Volume 3. The 14th SEASTAR2000 Workshop, Kyoto University, Japan.

Wyneken J, Lohmann KJ, Musick JA. 2013. The Biology of Sea Turtle, Volume III. CRC Press, New York. 